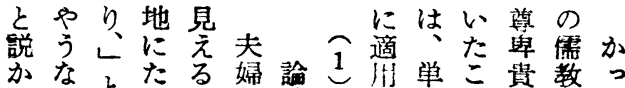

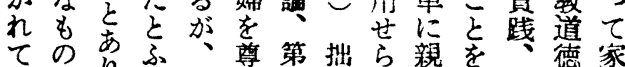

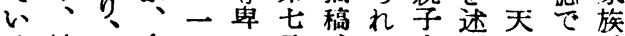

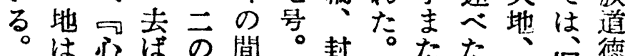

夫学夫例柄建注艻君旧嶶

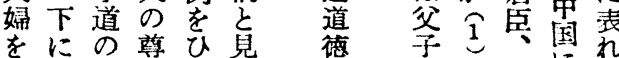

封

关在話きけなにたた本たた

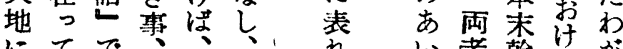

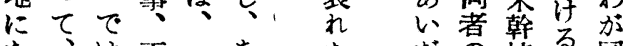

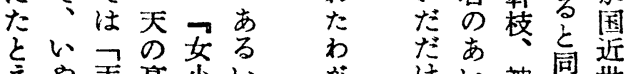

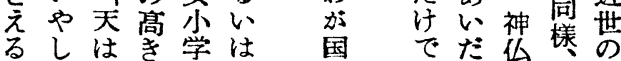

のい上が或近なの学親

は脄如に地世洒人子子

房在しつに次闐な関

夫のっ、夫た 親夫得のい係

をやて费はと婦絶閔しを

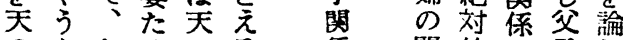

のなたるにる係閣的に李し

こもつ者喩語、係差比のた

そのとのへ、社に別定閏䟢

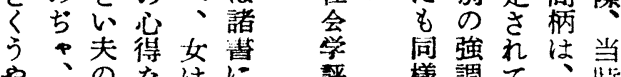

やしのなはに評様調て、辞

建
道
德
表
ね
た
夫
の
上
閶
係

はたをふてて逆様しいれがさを著ま つる以へ和れな無候うよ故ら天しひ

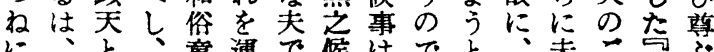

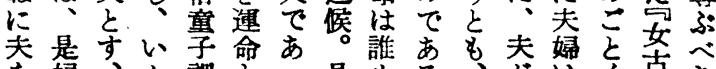
を婦、か訓之っ是もる。出は克き

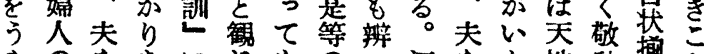

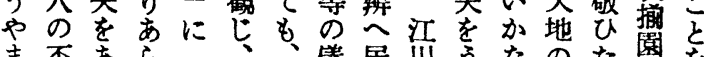

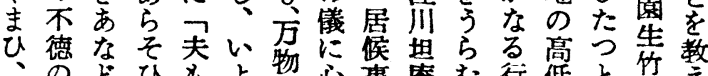

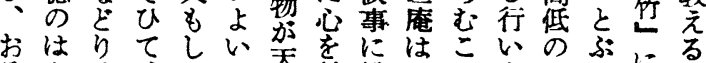

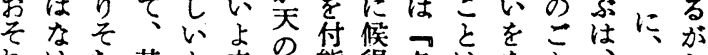

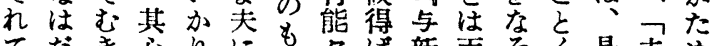

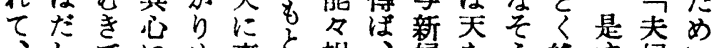

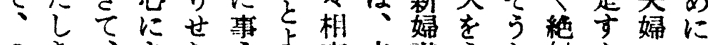

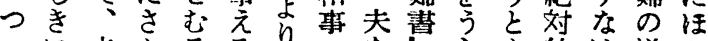

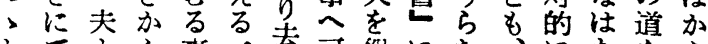

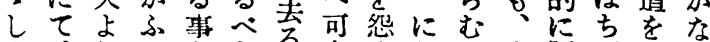

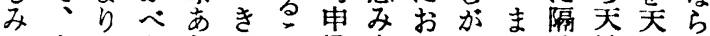
つ大心少らこ候先心こた絶地地な

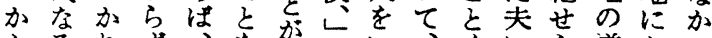
ふるりず、を㔔いい道たっ ベはせ、をさき教々ま愚よれなとた

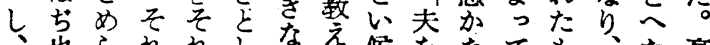

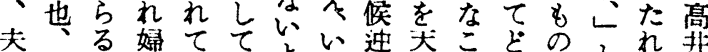

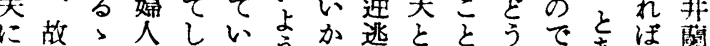
、ににはたるうに可いだ披あある、仙 や姑夫名。に悪抻たとわるる夫の 


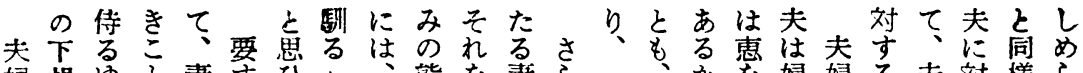

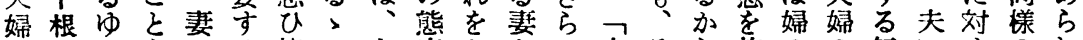
を总をはる慎にさ度吕とに夫そら施のの無にすのれ

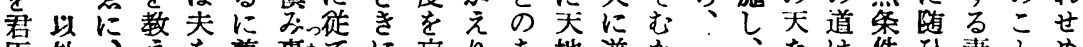

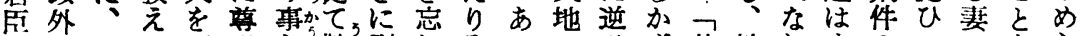
・にあた天鿓ら敬引れみいのひず其地りまのつの去ら

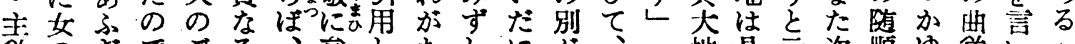

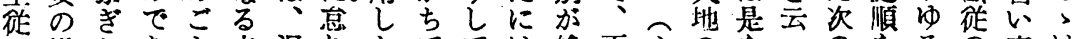
に道たあを夫過りたででは絶天心の怘ののをるの表は 準はふっくと少、言あ畍、対の学御うりよ要をすし

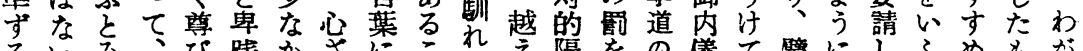

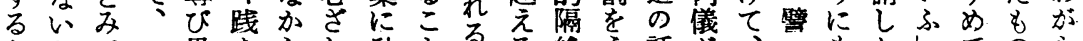

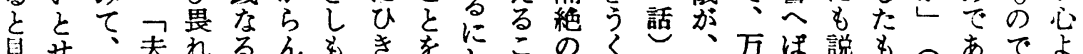

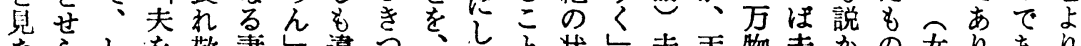

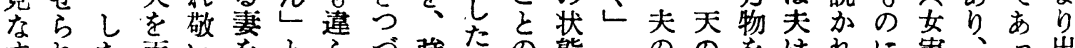

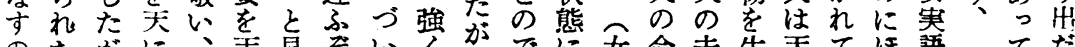

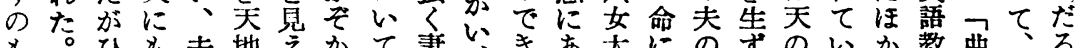

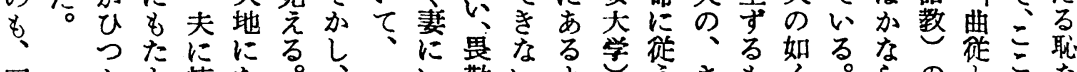

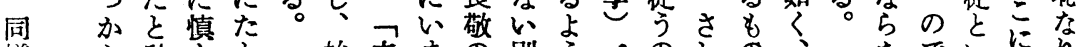

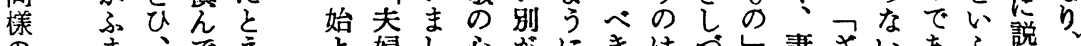

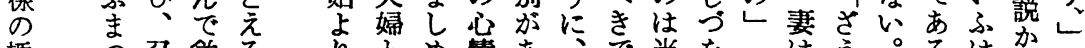

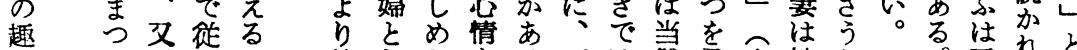

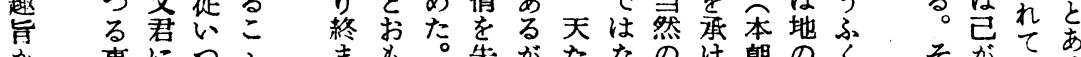

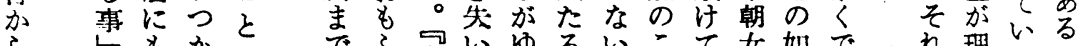

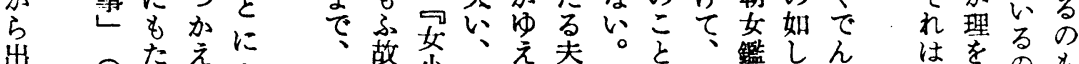

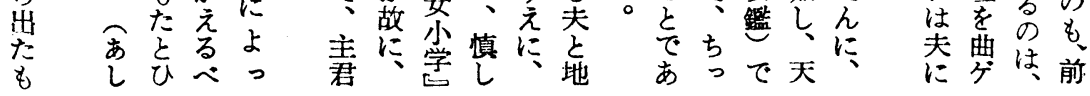

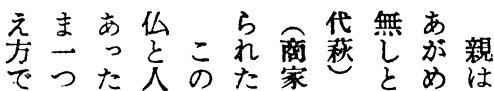
あの茂間よ。㝟でやな子 る别、のう聞あらけに

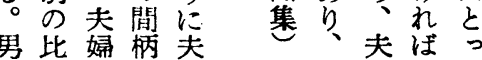

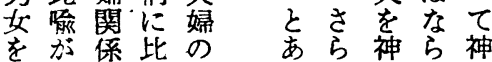
陰用に定関るにとな仏

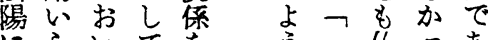
にらいてをう二仏っあ 配㣗て論

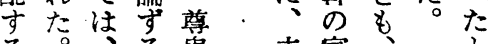
る々親る貫 婦に大家姫同 はれ子を賻 は関は

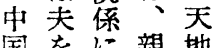
国をに親地 古陽は子 来㝟関君 の妻ら係臣 観をれの 念陰な暏本 でと加合末 党つと筷 るなた同枝 と芓い翟神
るに人あがし句婦なこをこの

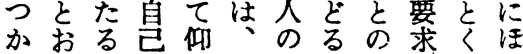
へも。老直主ぜ主 、ひっ奉、女は否らこな 右去姰公つ大人らとれ女ら の夫家人つ学にず惫た実な 衆鼻のししし、ひ。語加 中主婯地んにたやて、教っ の人焦位でもがは、和たた 仰々心に見ふらう俗と をおにおの元にき童い? 直统は命てあしま子う夫 に住、、にいらたひ訓交は う奉嫁主絶る允吕つ各た け公は人対。元ひ>のはと て人舅た服武いてし、会

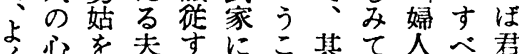

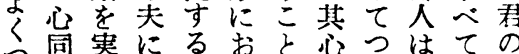
々やの私こいは蝴のこ

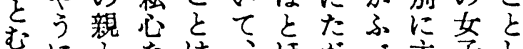

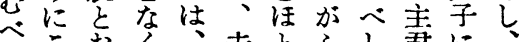

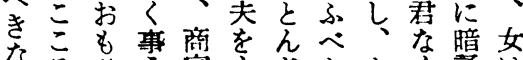

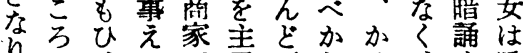

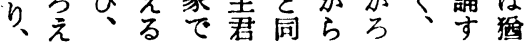

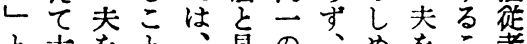

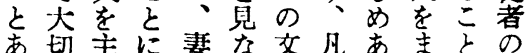




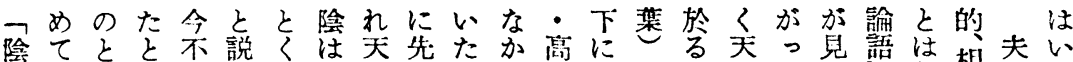

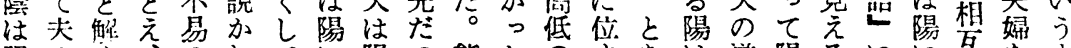
陽のす市れてに陽つ熊たのすあ湴陽るにに辛をま

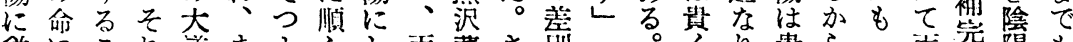

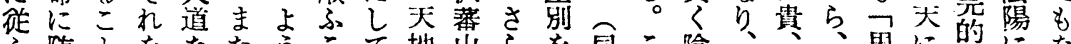

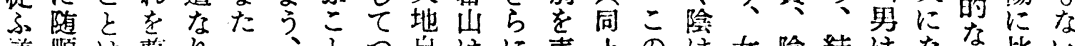

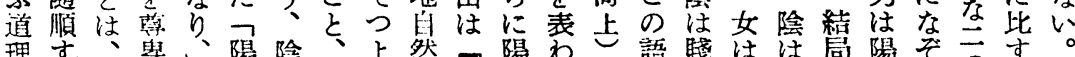
理す、舁し陽陰よ然陽わ語賤はは局陽ぞうす

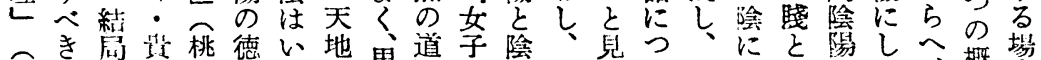

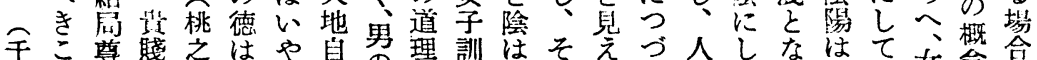

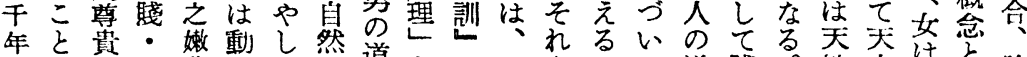

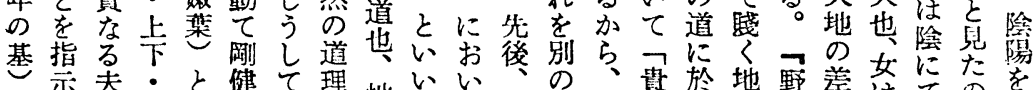

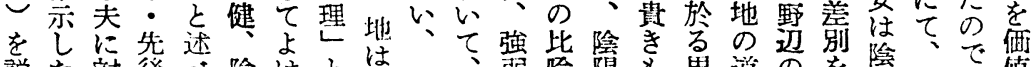

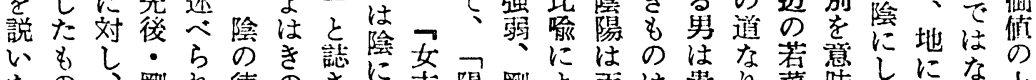

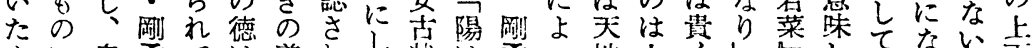

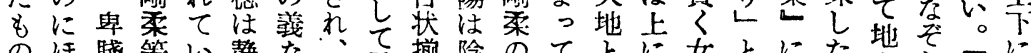
のほ賤等い静な柔揃䧔のてとに好にた地尔うに

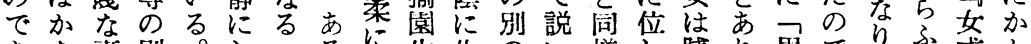

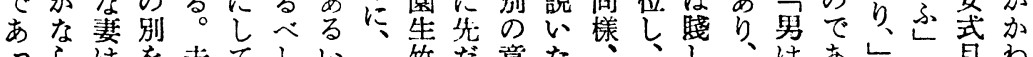

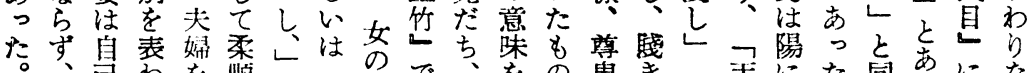

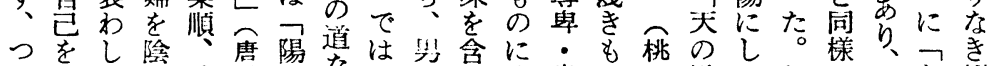
またた陽是錦はな忙先贵のの道てしのてお相

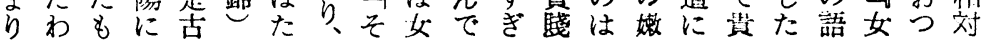

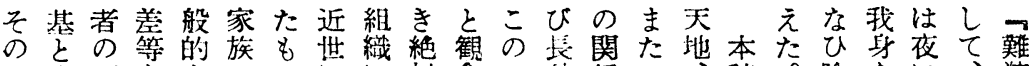

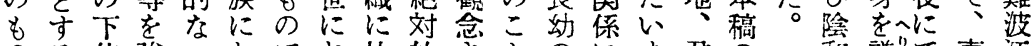
のる位強一おでお比的さとのにま君のの和謙くて専江

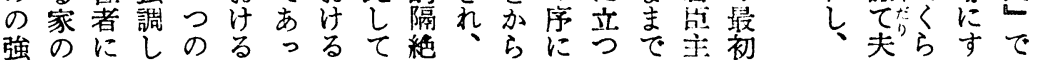

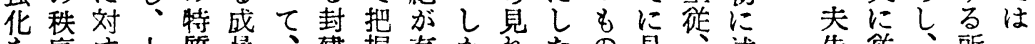
を序す上質是、建握存加れたの見述先隹、所了

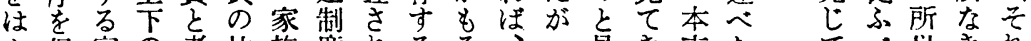

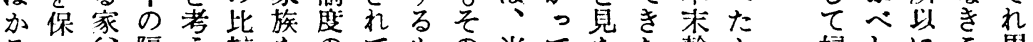
万父隔え較をのてもの当てなた翰よ婦しにこ男

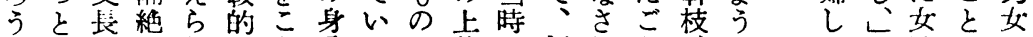

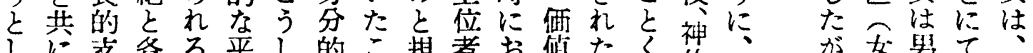

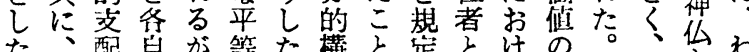

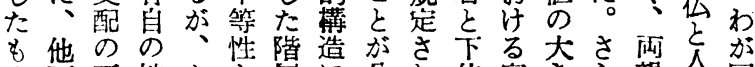
の面可地加厤に分拄位家きら親開国

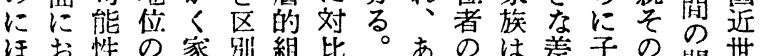

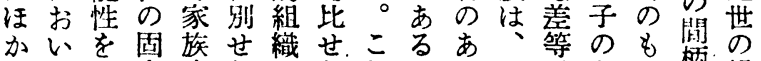

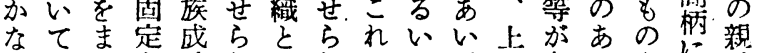

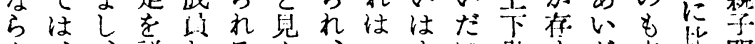

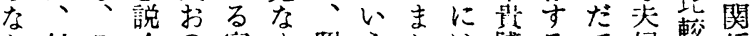

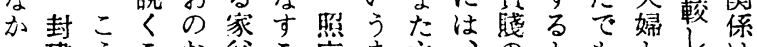

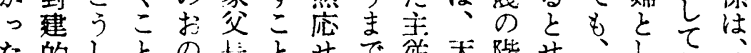

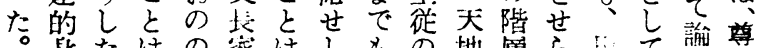

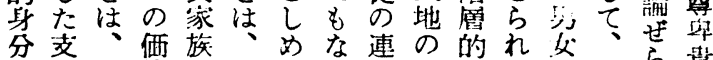

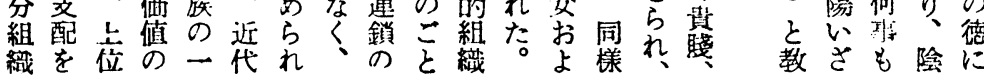

子大に候则

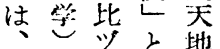
月とる障 然さにわ陽 の 道さ 也諰惫㻎 乞蕃る流 女出故陰女 子はに性は 訓ᄀ、陰 陽何りの 孝さ教さ隐に 


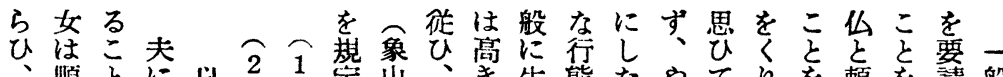

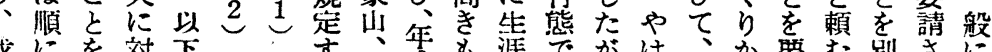

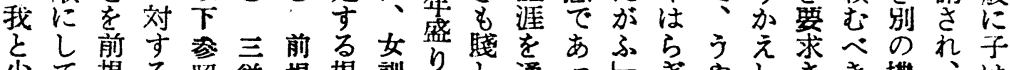
少て提る照従揭根訓にし通っしきやしさき機、は

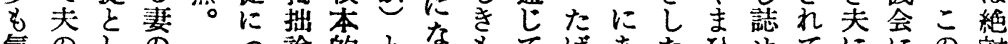

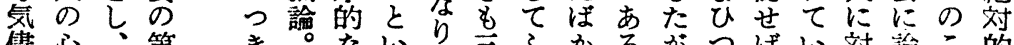

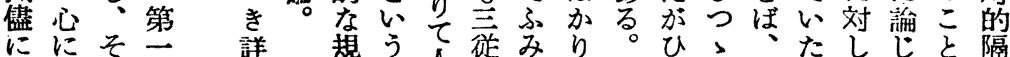

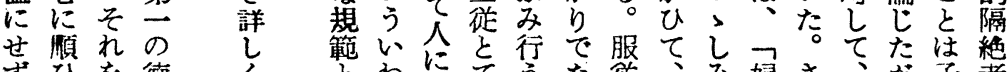

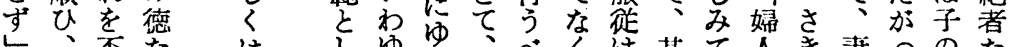

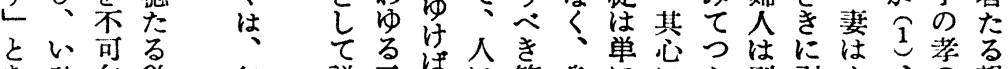

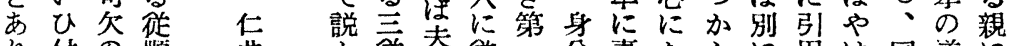

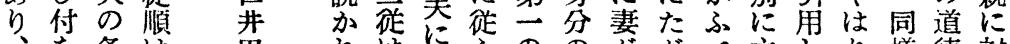

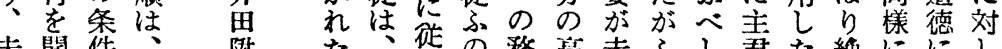

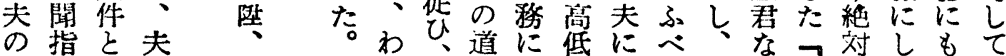

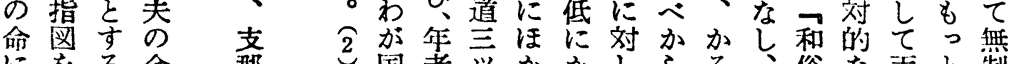
にをる命那国老产加加ら万华な天と制 絶う。令身年侍なかてずし夫童服でも約

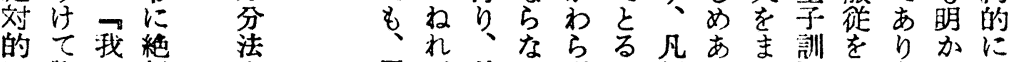
に物つ対史男ば幼かずへ婦なこにさ主に服

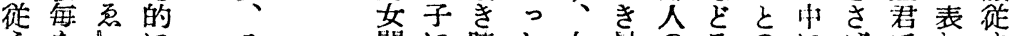
うを公間に時た蕰のるのに沙てれ等 汇取に服五の佂は。性も道心主あるあてる

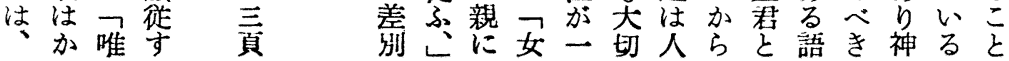

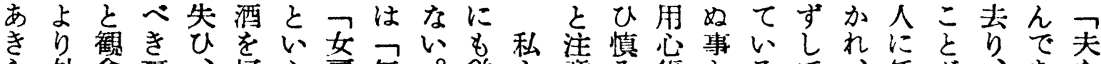

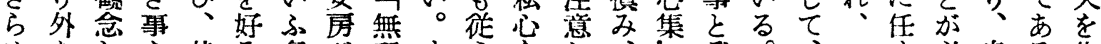

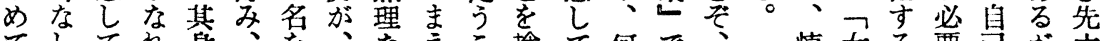

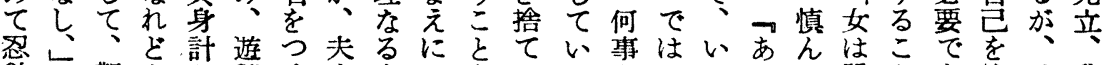

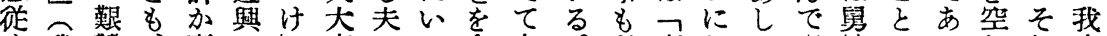
す我難、妻にし事にっ含夫私妻しの具姑にっしれ身

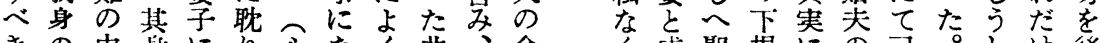

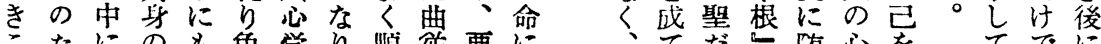

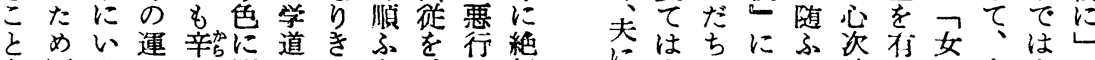

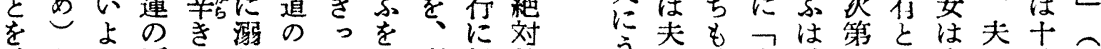

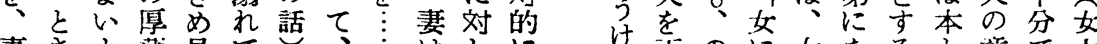

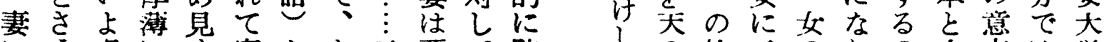

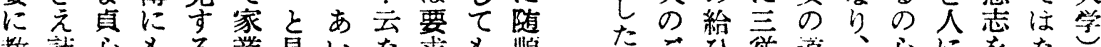

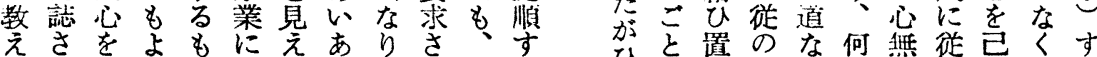

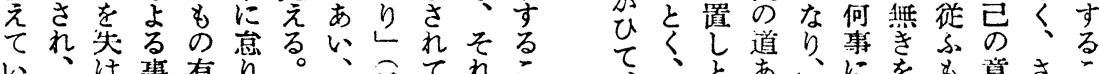

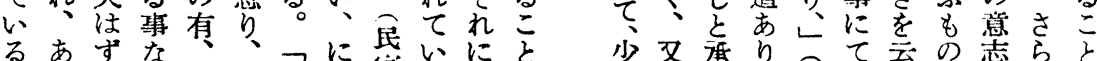

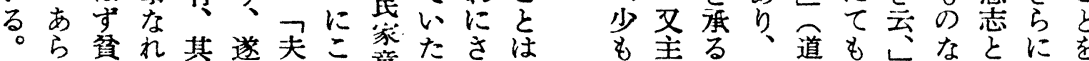

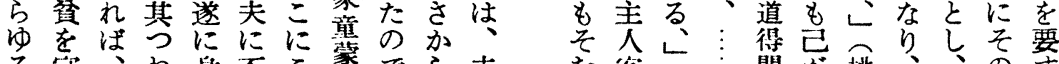

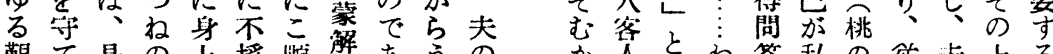

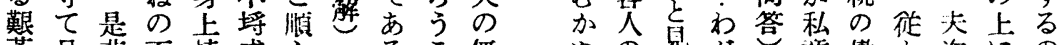

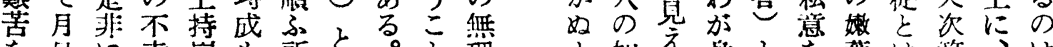

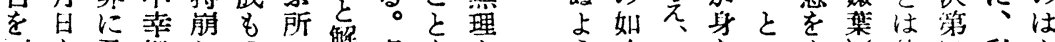

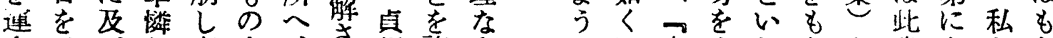

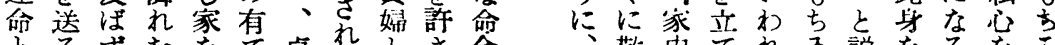

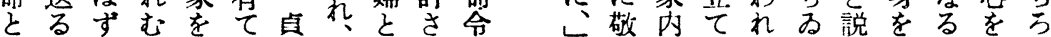


か同っ素れる物っら想ととてとそをおさあらでは

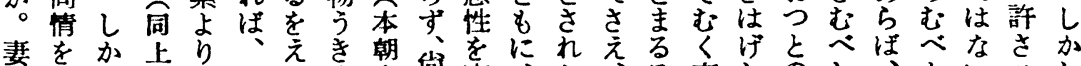

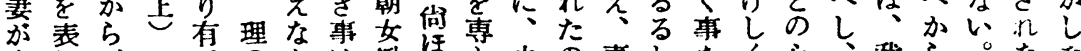

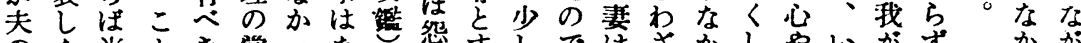

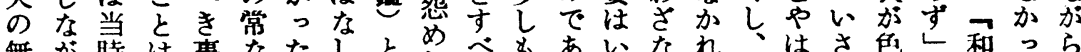

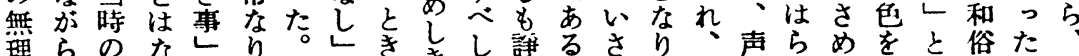

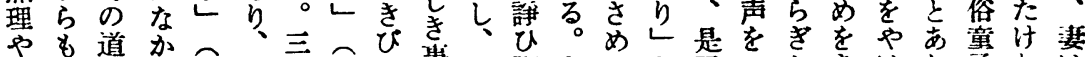

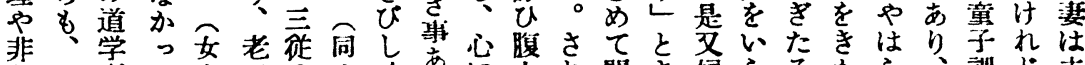

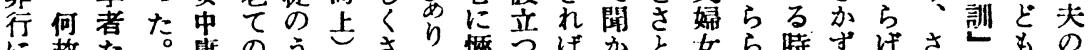

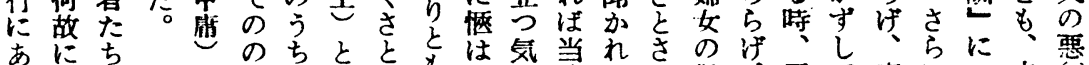

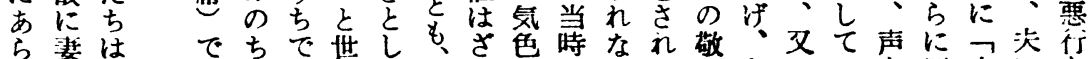

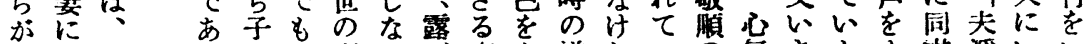

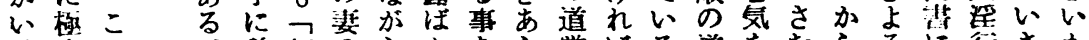
、度の肪行のら幻あら学注る道をむらろに行さか

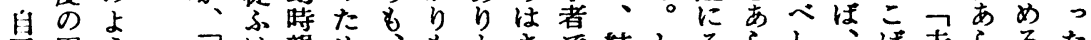

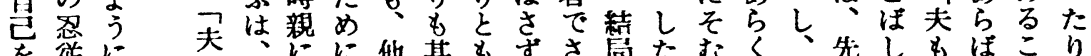

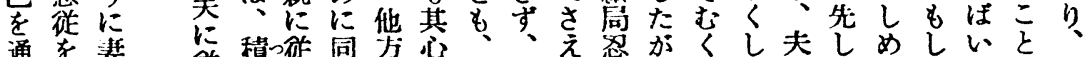

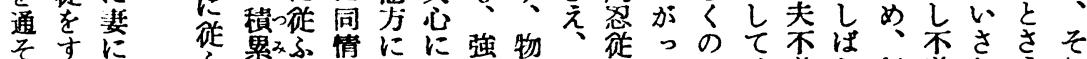

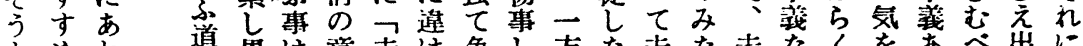
とめわ道恩は意夫は争し方な头な夫なくをあべ出に

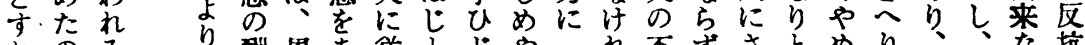

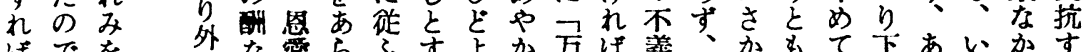

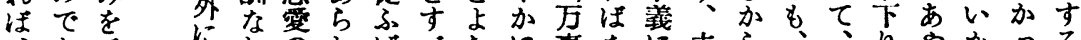

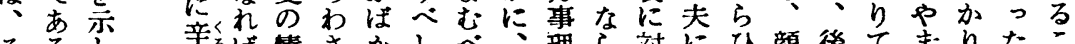

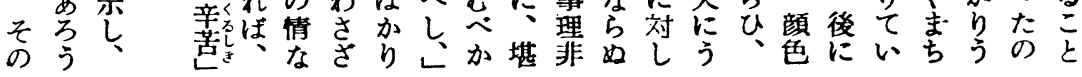

しいへにつずなると内があけの思と夫ぶ保家忍を結

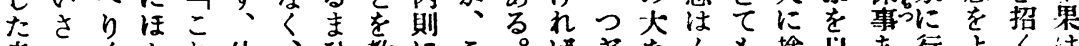

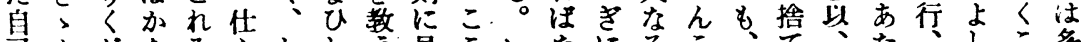
㞯加なみふししえ見こいなにるこ先て后たた多

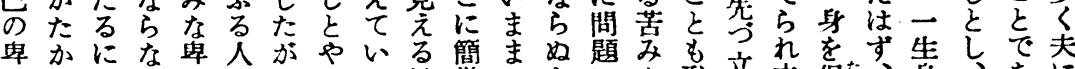

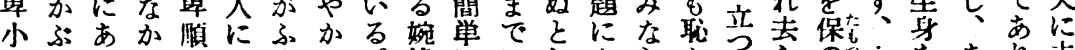

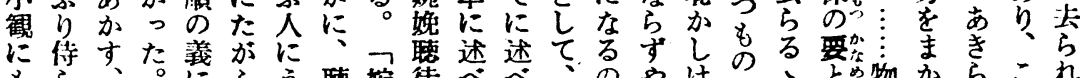

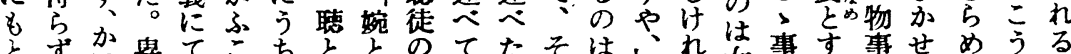

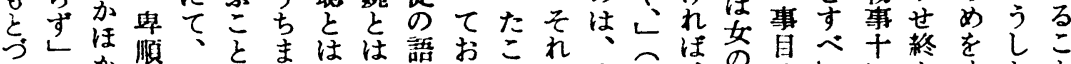

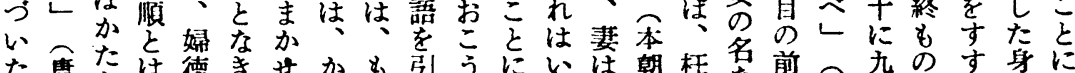

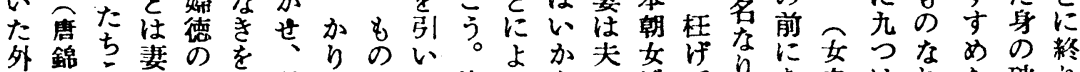

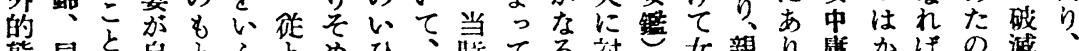

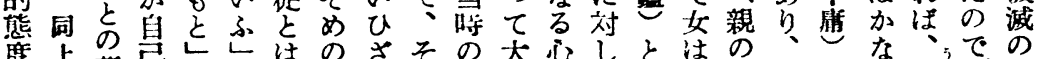

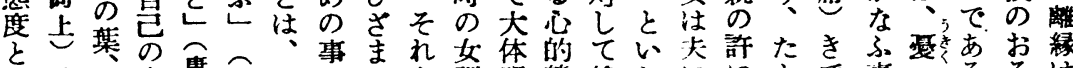

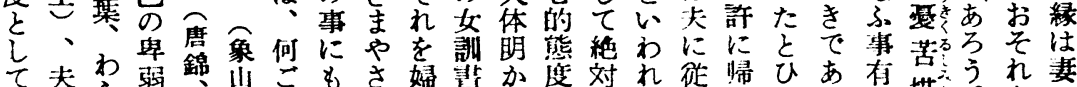

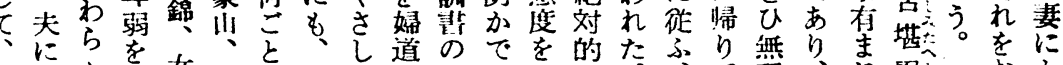

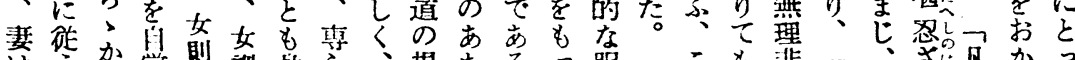

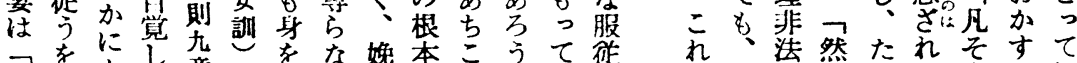

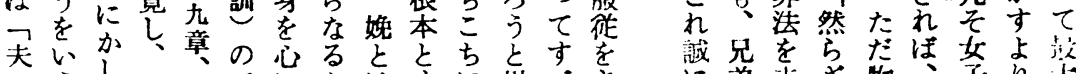

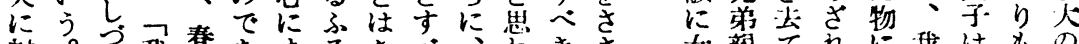

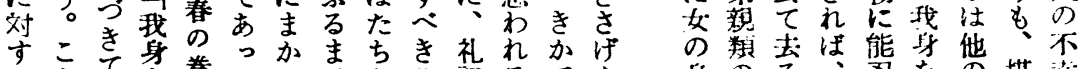

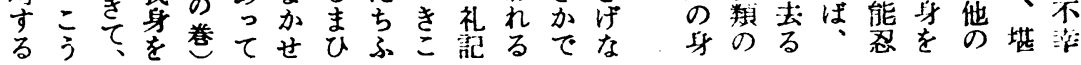


立道じはとら来るの规㜪售だ、表た然こに手るのに

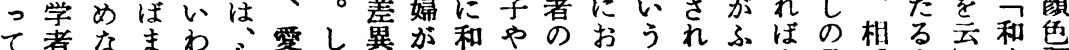

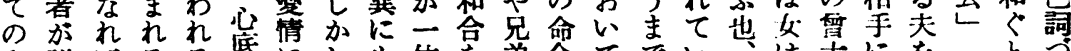

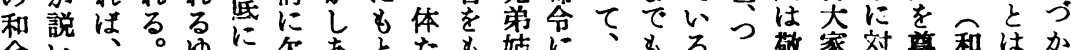

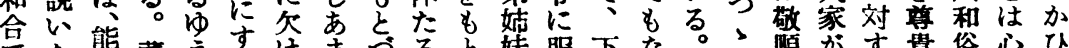

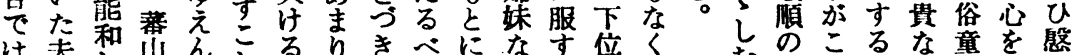

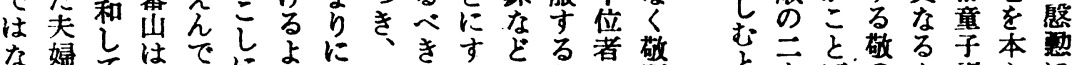

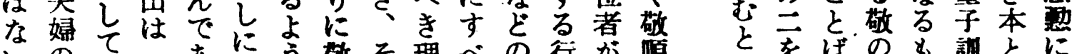

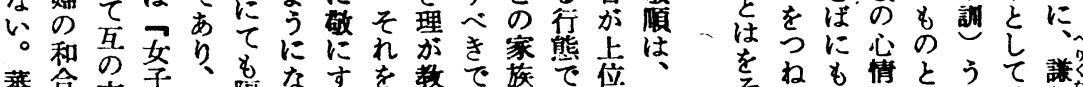

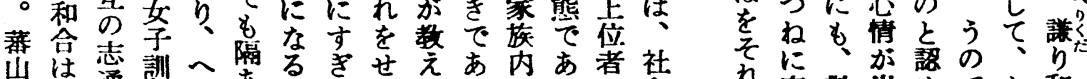

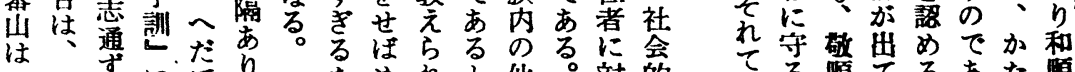

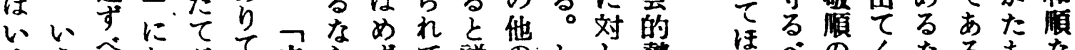

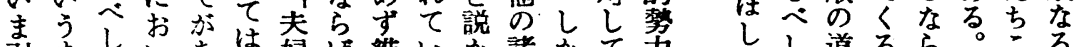

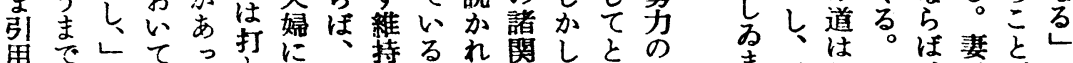

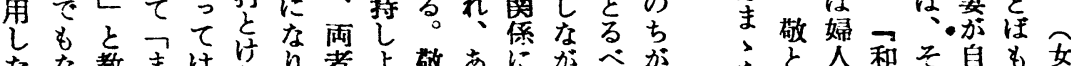

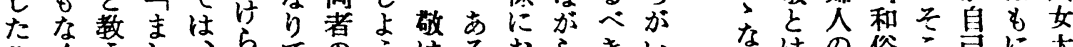

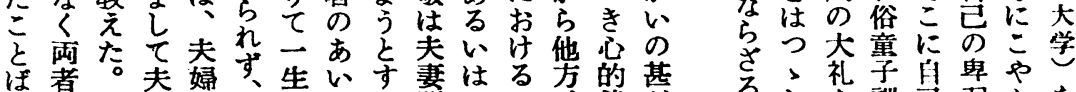
ほ者。夫婦全生い妻はる方的甚 に方け婦のし我たる間さよ態た

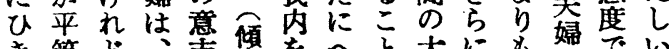

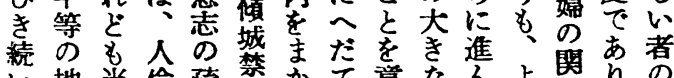

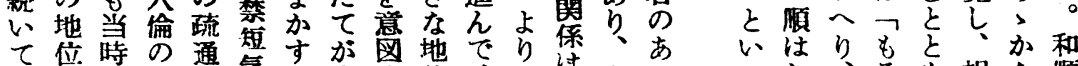

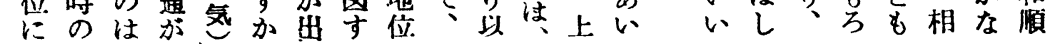

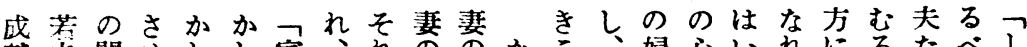

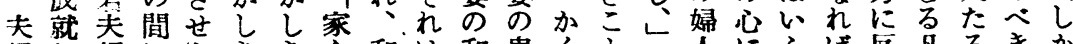

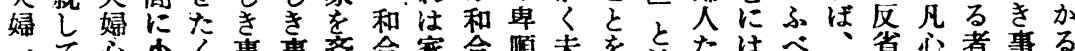

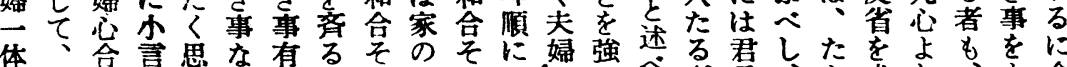

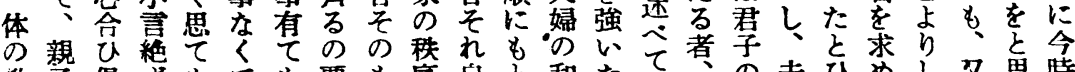

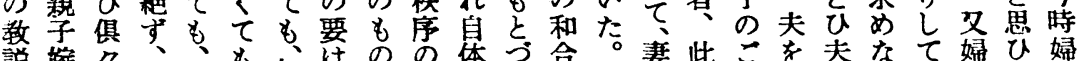

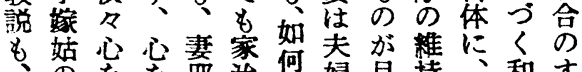

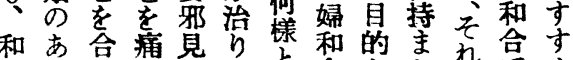

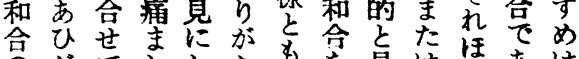

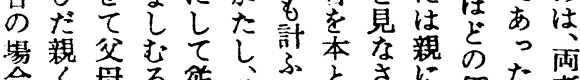

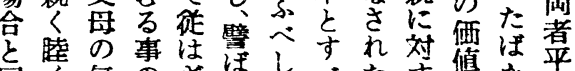

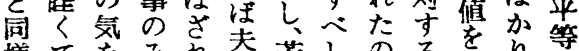
样てをみれ夫若しのる認り等

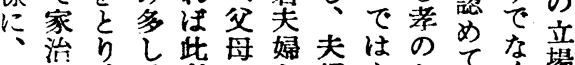

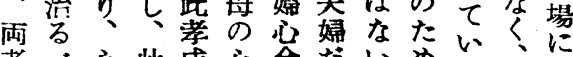

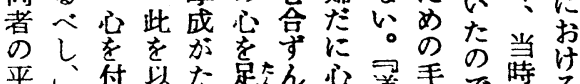
平し付以た跨ん道手で時る

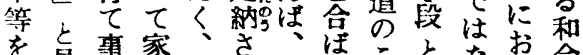

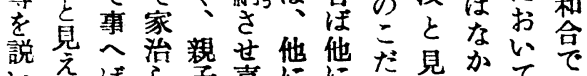

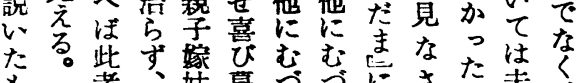
妻此こを夫なて婦ひ婦 の婜と君はが二人てた が婦く子否ら家の、る わのにと足も和不わ者 に心おいな和足㤎は のなもへり精せの身 みらふると筒す、みた

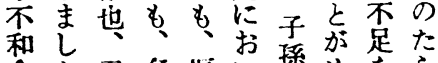
合加弗名据い称め老ら

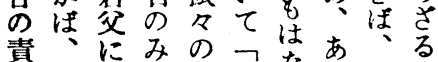

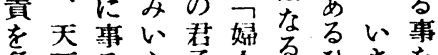

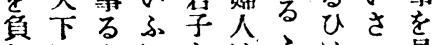
わに它に告事は見 せ不屾思真全加て 是同あふ正あ方㐫は 夫の异方純り方市

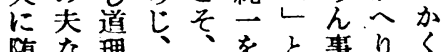
随な理、索事りく

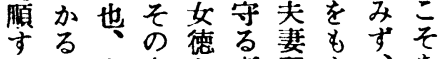
穴世女と者齐と、市 
夫てつの尽わつう㜟に夫のとくと和たるるめ夫通の

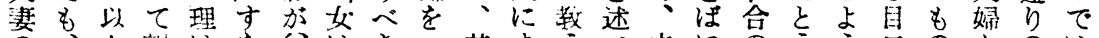

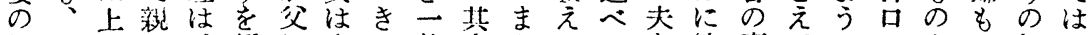

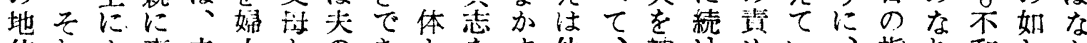

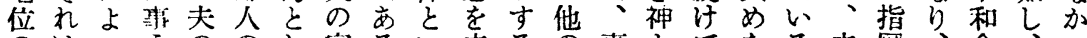
のはっえののし家るい夫るの䒹とてをる夫図、合、る

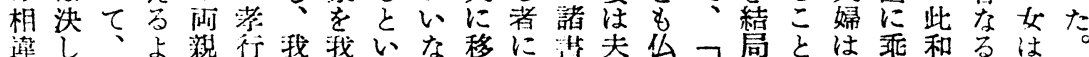

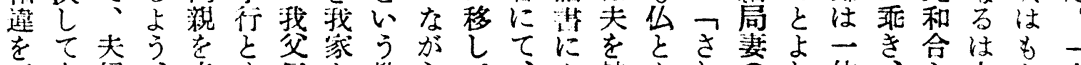

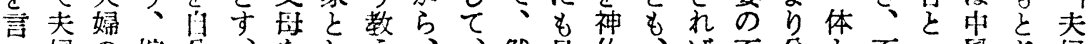

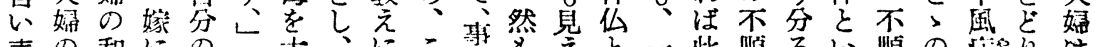

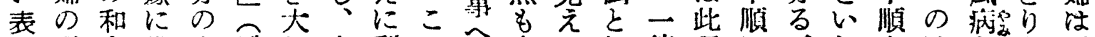

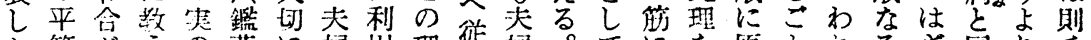

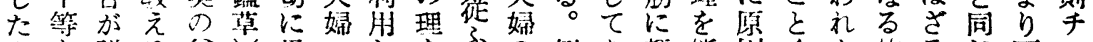

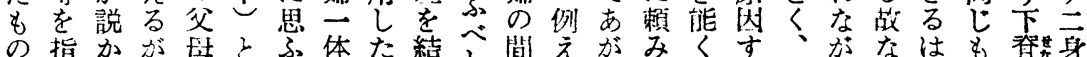

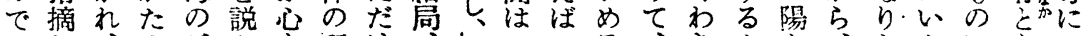

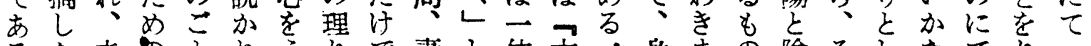
るた夫のとれうりで费と体本命身まの陰そしなてり二 こも婦理くてつなあはあな湖きをへをのれるれ体

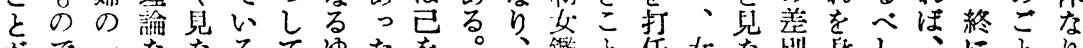

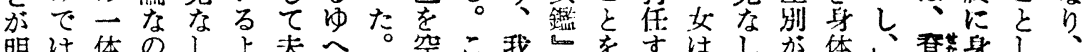

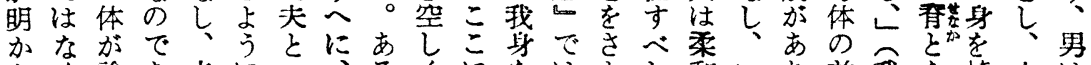

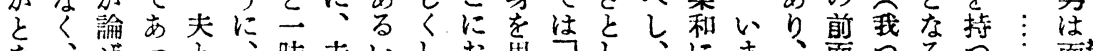

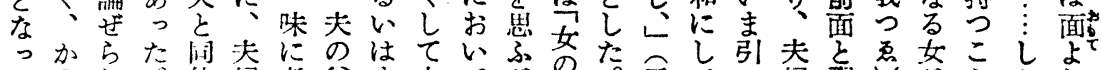

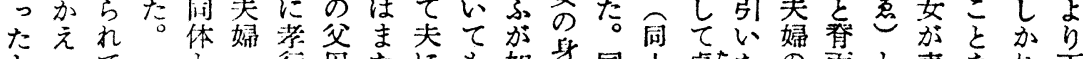

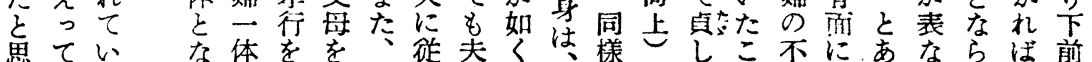

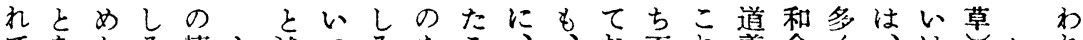

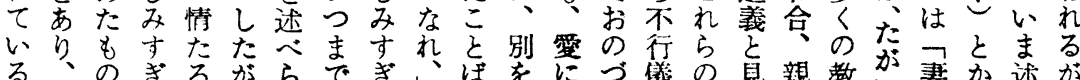

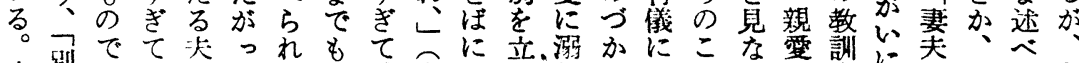

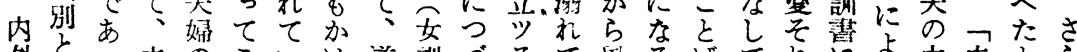

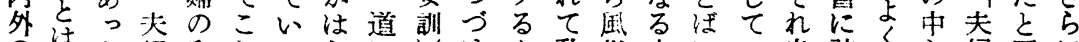

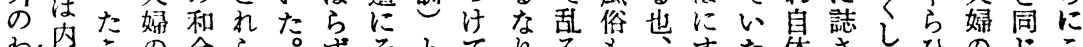

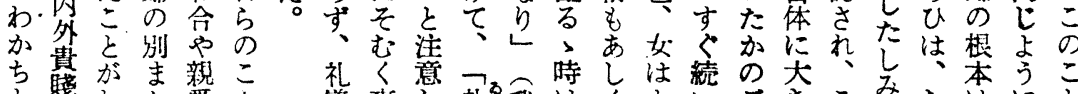

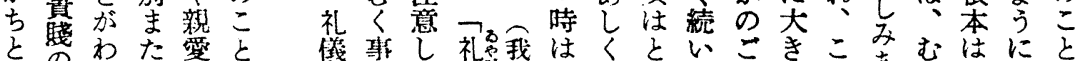

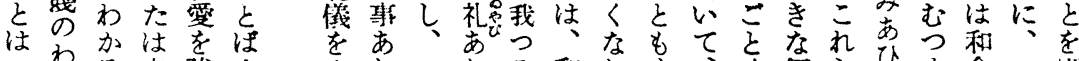

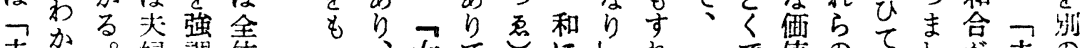

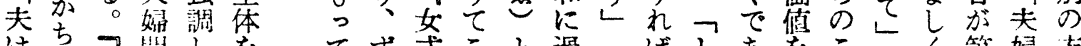

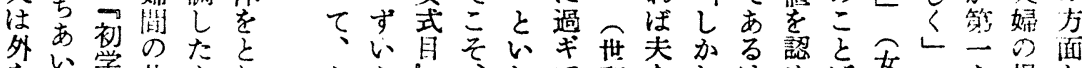
学礼多 お鼬部をのあ さ乱にわでげ め乱にすはる せ夫れなな 婦る婦がら

内也纱芯反宁 おと道る神䦌 さ説とのなの し明すをれ自 めさん戒親 然

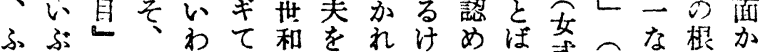
うんでをれ和多名をれれた式乘り元ら

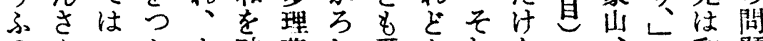
のな子とま破草し愛もれを和題

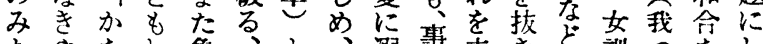

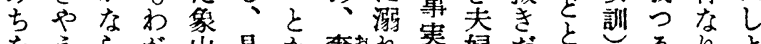

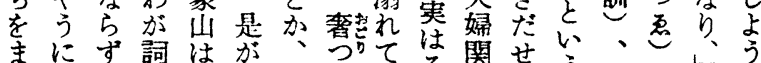

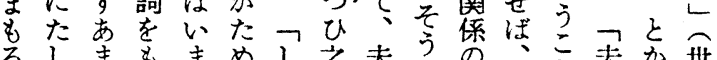

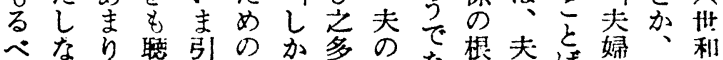
しみしく用ゆれく身な本婦はのあ多 
天戝の

地な差以

- る兾上

君妻のに

臣の絶述

- 敬対

本順性た

来を幹䒚う

枝す調に

等め、、

比曲々建

踏従㣗的

ををに・

も も 隭

七強方教

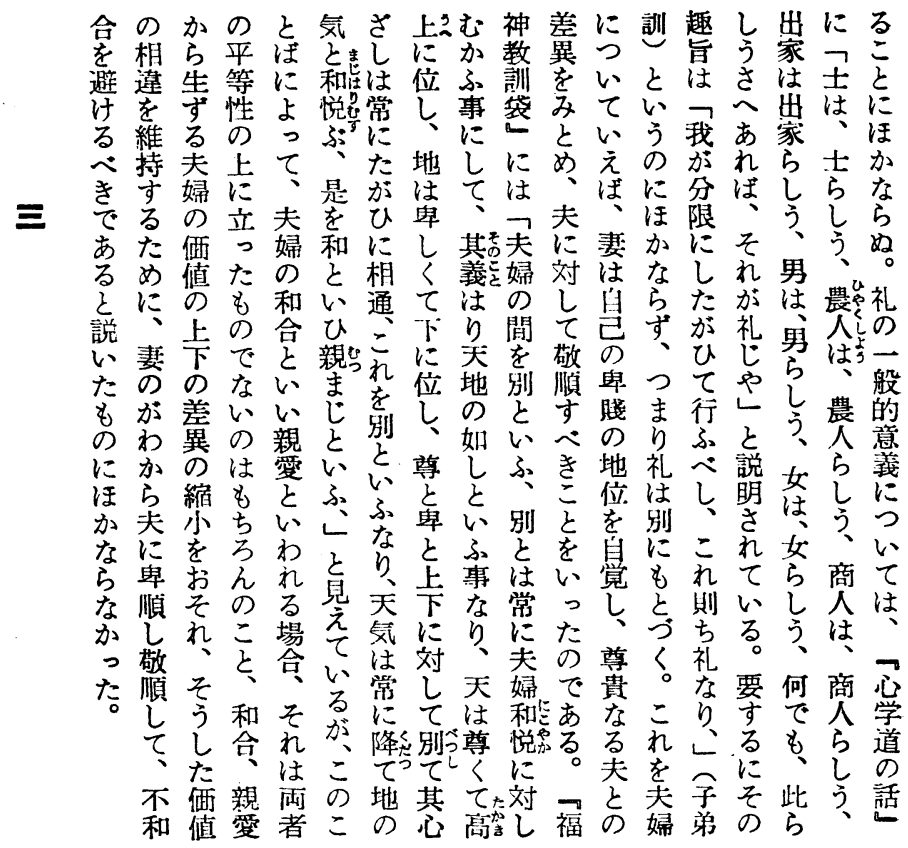

夫たて婦

との尊道

ので 貴徳

価あなは、

侹っるる

隔。に妻

絶 计対䦓

をれすの

上も卑值

思すき作わらう尊一一よ及のいは意すれ生らにとか わる誌用がれま需嬻般り異両では識るば活なくはら

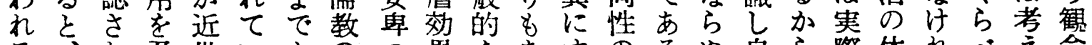

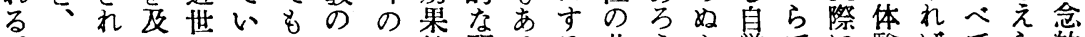
そた浪にたな両思的関るる共うと賞でに験ぼてら的 女れ女しおこい性梖で俰意亡同。いしあおかなのれに

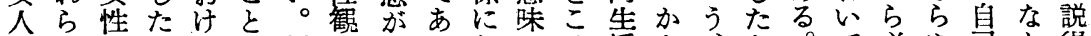

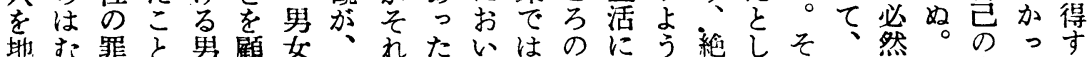
地む罪々男顧女姉たいはのにう絶しそ然。のうす

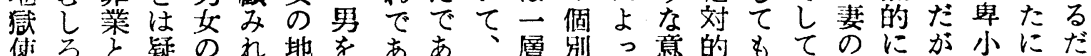

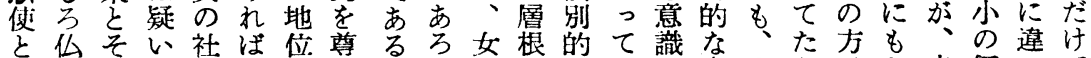
み教のを会明をし 的性 心的加陰 外な質れ・で陽し 偝のな家あに 如性邪心庭る比女

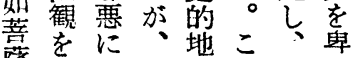
薩を関当位学陰し 内多方時のな陽き 心詳種定な乾の 㠰継細々に儒坤と 夜康なの效教。 叉指女し的天た る る 摘訓根男地こ 評もを畫本女にと の 検に的観 配 は しと討書ながせい

う性源な現な卑夫と莎た夫洒いで の的夫実い小に心夫ら婦值交 個ᄀで婦にし意対一よさのをい妻 々先亦闇体自識し般り杂洒は。の の天る係験覚がて的尊る值っそ絶 現的とにさを必然に貴とのきう対 実な气お杂娎然条、で隔りし的 のしろい、に的件伍あ限絶自た服 事卑のて価植にの倬りらの覚服位 例賤、で值え出服の、な自す従が

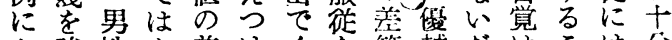
か強性な差けく等越だはこは分 加調詨く簧るるさをせる、と、に

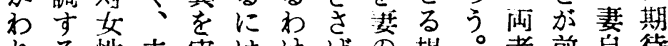

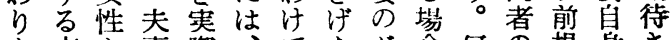
な方と妻際、でなが合何の提身さ

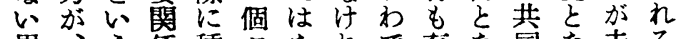
男、う係種々なれで存な同な夫る 
にまなそくこ盒っ多徒援鹳時しれい定わえ説観姑

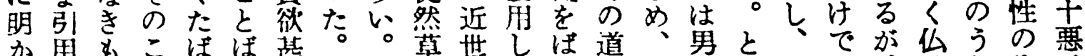

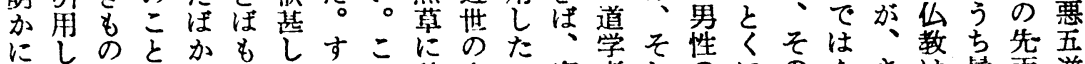

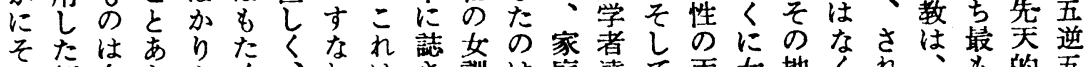

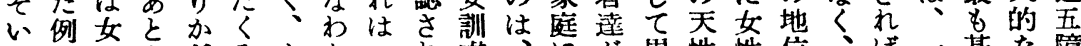

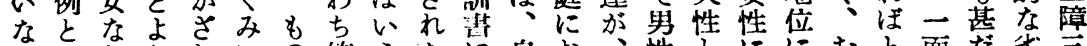
がしりり杂にの第うたに自お、性とににむと面た劣主 らてしある苦の百ま婊然け一航は対園しいにし位良 、はとらこし理七で性れなる般の全し定ろっおい。

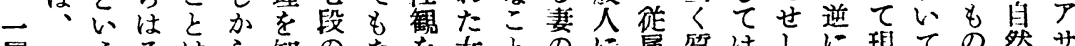
層つうるはら知のなを姑にのに属質はしに琴ての然サ

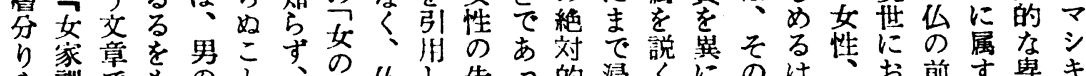
や訓で\&のと、性㕕し、先っ的浸くにのは湔す卑キ

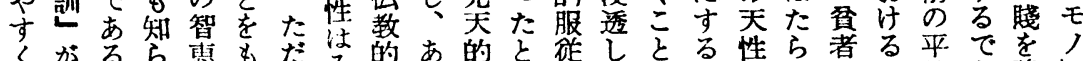

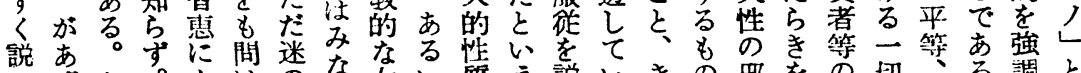

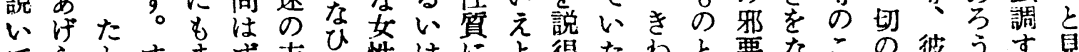
てらとすまず方占性はによ得たわと恵なこの彼うすす見

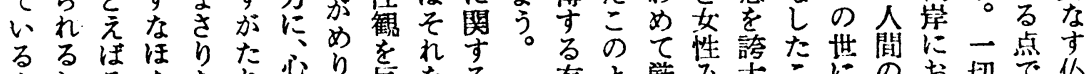

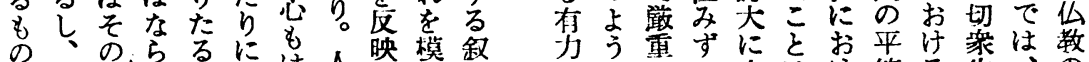

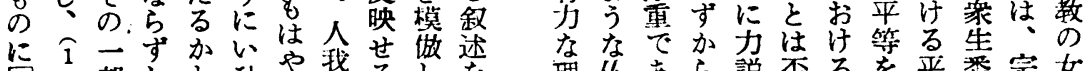

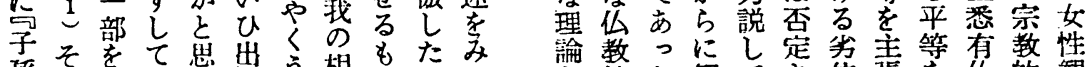

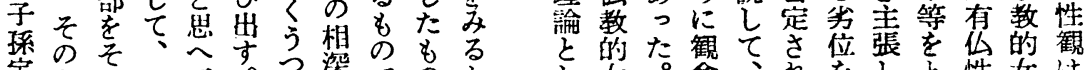

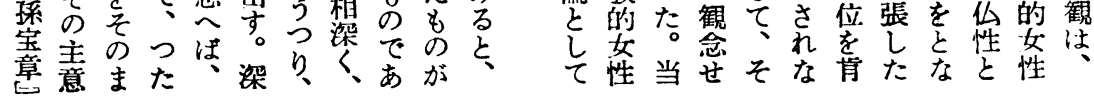

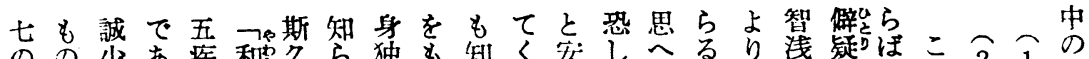

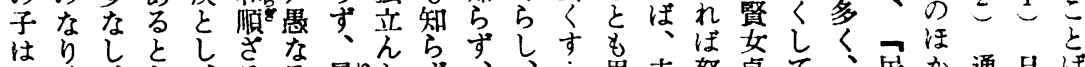

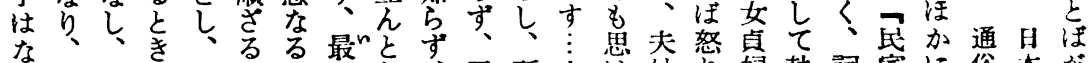

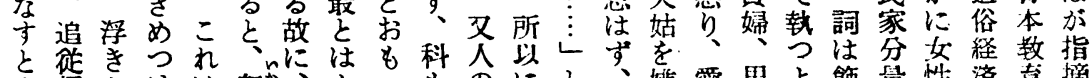
も軽たけは怒妿、かへものにと、㴋愛男よ飾量性済青摘

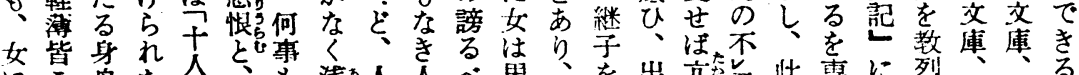

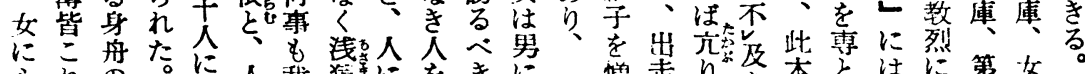
心れの。に人我獾にをきに憎走り交本とはに第好。

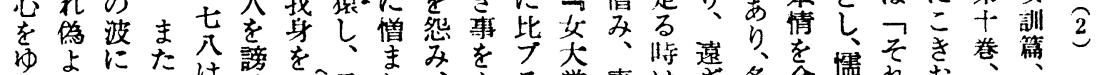

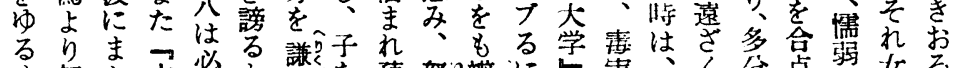

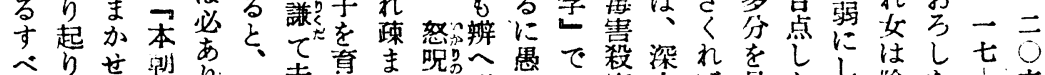

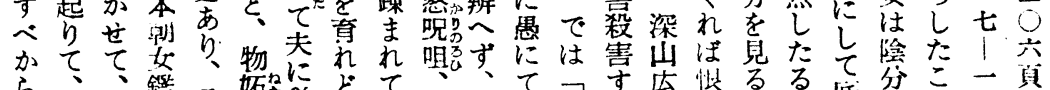

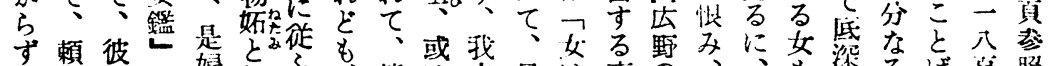

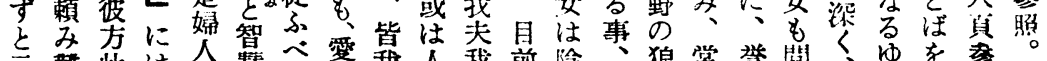

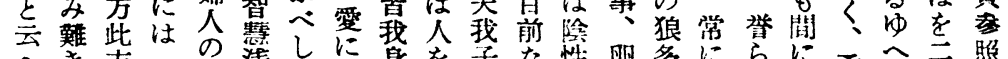

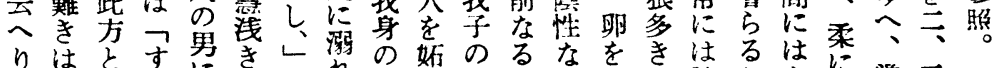

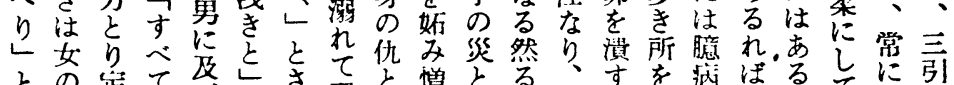

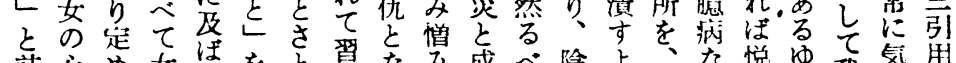

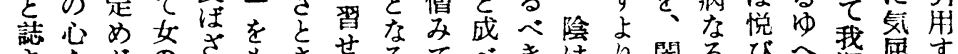

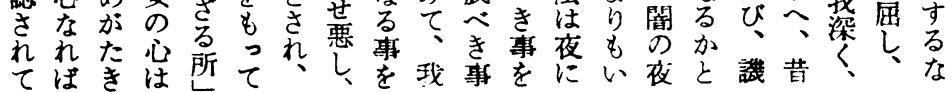




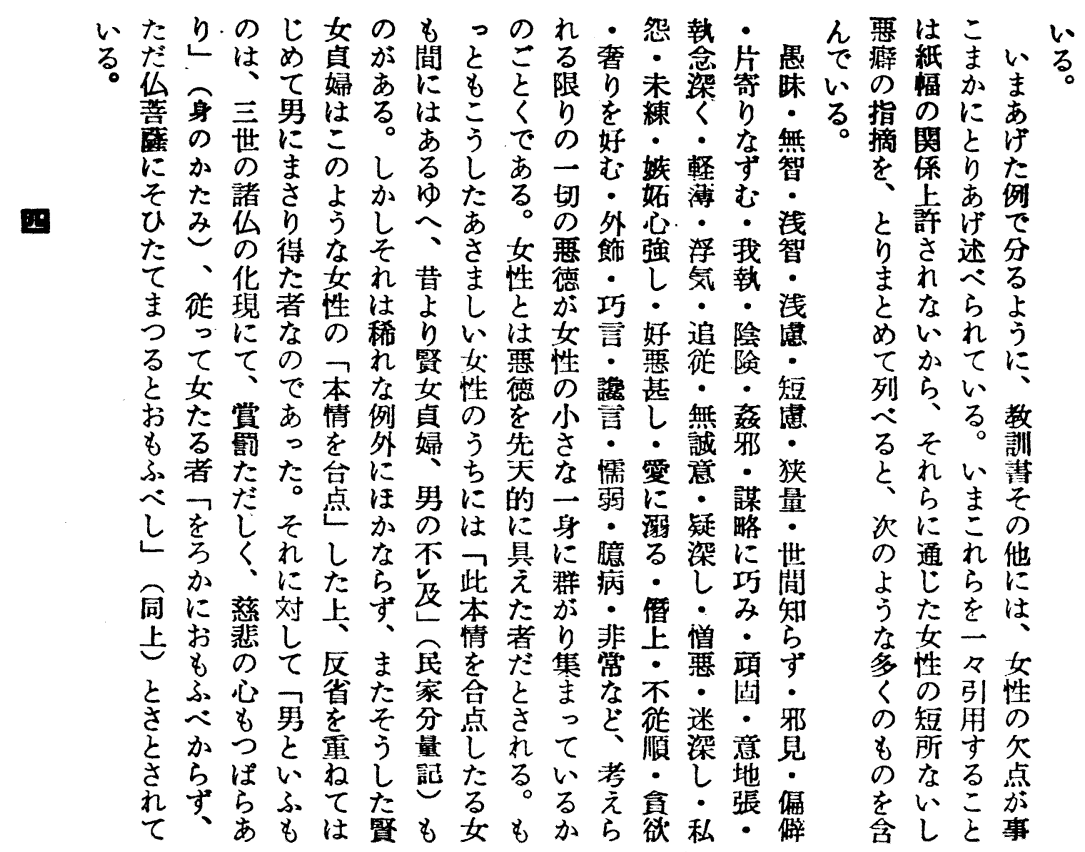

で悪るへるしふ其男性は見たえす良はと古ずさ罪

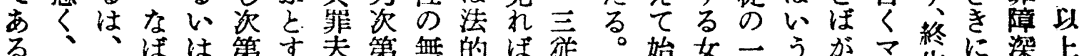

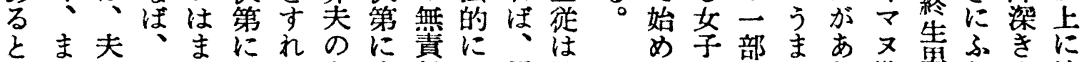

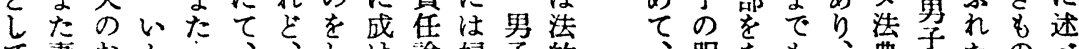

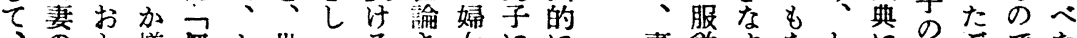

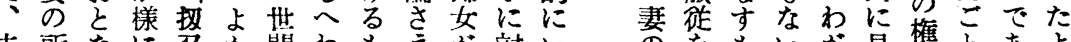

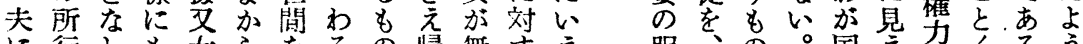

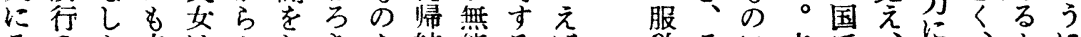

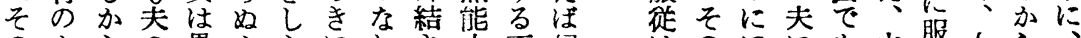
のよらの愚心らにれさ力不婦注のほにも中莳女ら

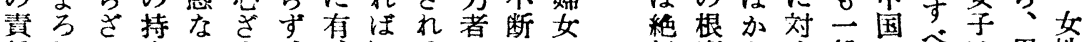

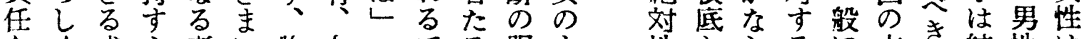
をく成心者に物女。てる菔永性々らるに古さ結性は

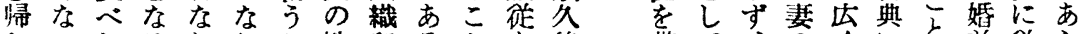
しいしるれりた性留うとを後带て、のくに前徉ら

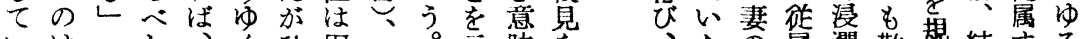

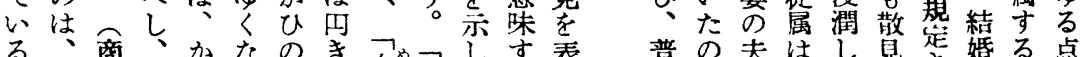
る、商、かなのき始つしす表 普の夫壮し見さ婚る点

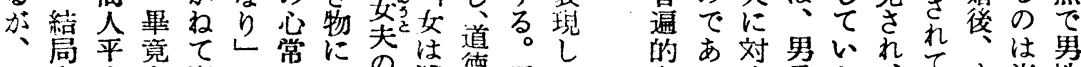

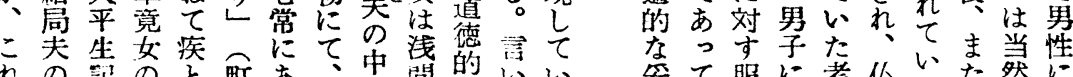
れの脚のと町あ、中間的いい妥て服に考仏いた灵に

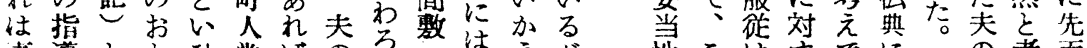

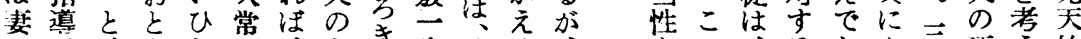

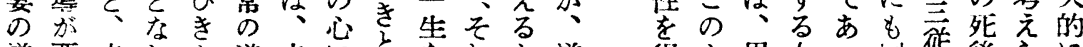

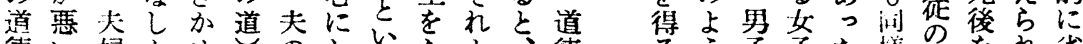

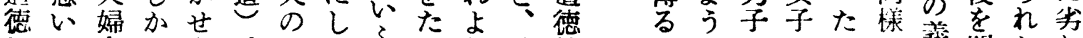

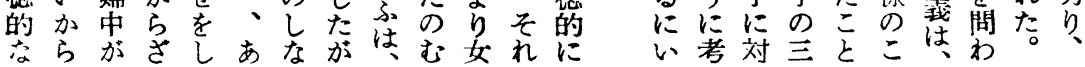




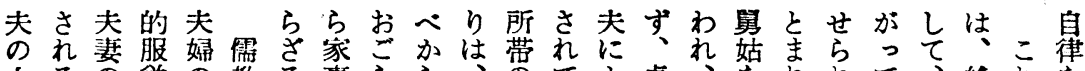

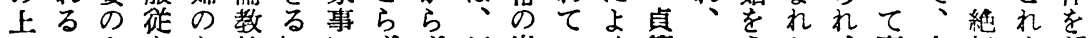

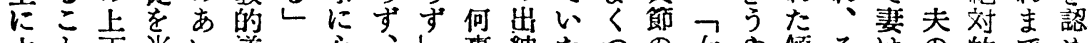

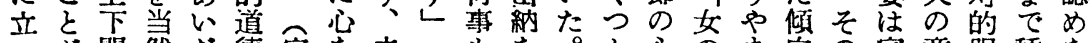
号関然た德家を夫っもを。か心のま向の家意服種な

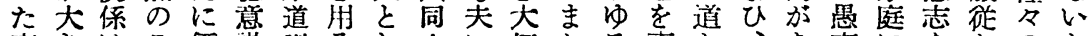

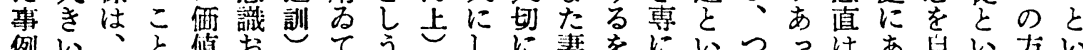
例

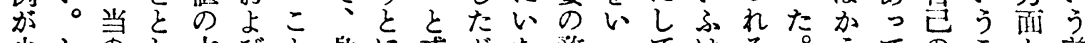
少しの乞大ひを身に我がた猛へてはそ。えてのこか前

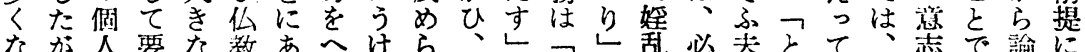

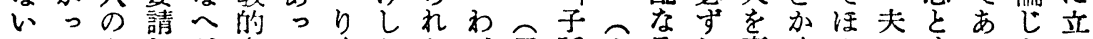

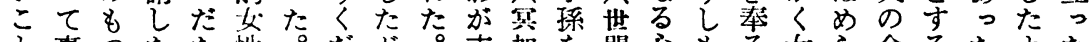

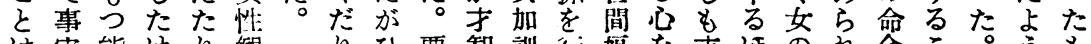

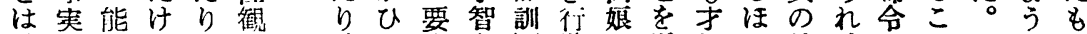

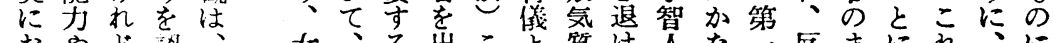

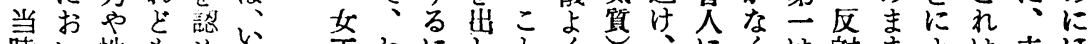

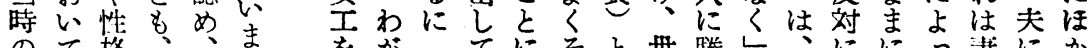

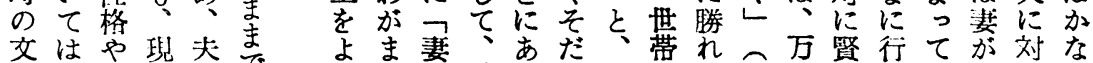

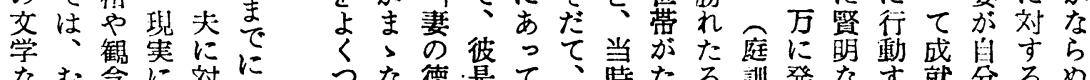

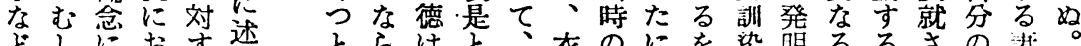

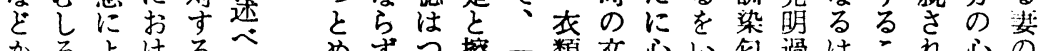

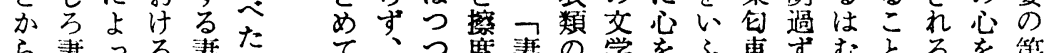

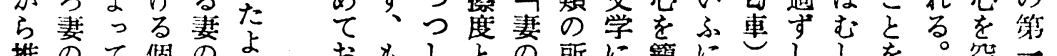

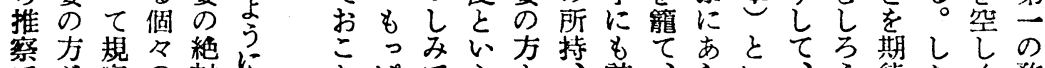

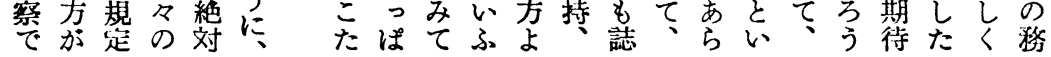

るめわ男優番あ神男や生にた実の戴なおのく、見き

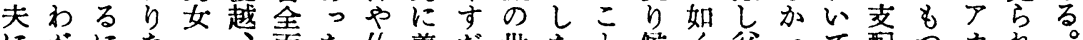
にがにな的面た仏僐だ世たと候く爷って配つカれ

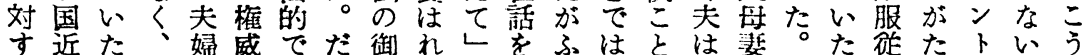

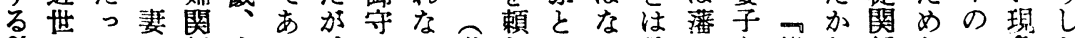
從のたに係支っ、もが道むいい是のを媒々俰とい像た 順夫こ対を配た妻方得なふ。な样はの云の考うで上

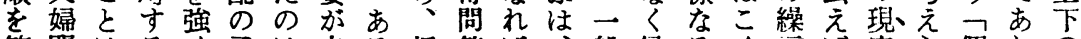

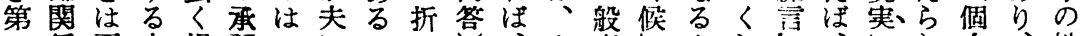

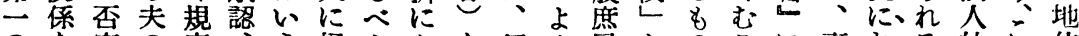
のを定の定う経からを何め民とのこに琴おる的京位

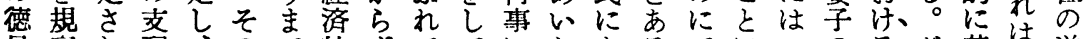

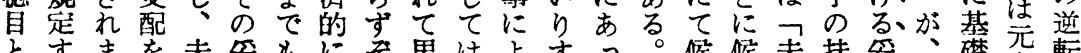

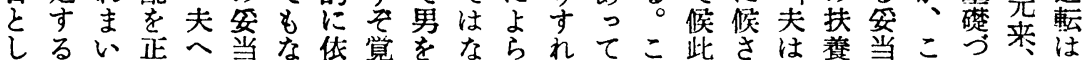

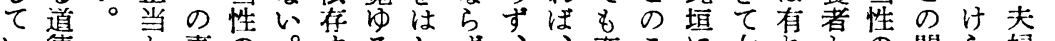
、德々妻の。守るしず、变こに如々の間ら婦一

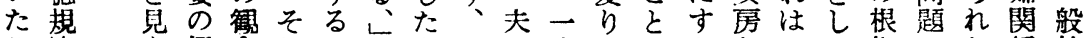
こ範な経念しここなに生注注加こて扰はた係的

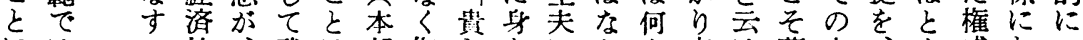

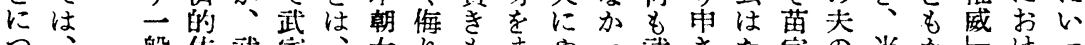
つ、般低武家、女り毛队口武さた字の当加忊っ い妻的存士に武爁お戤汃した家守と知役時くのるて

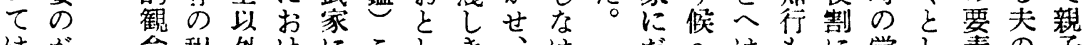

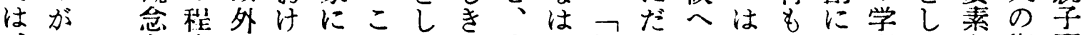

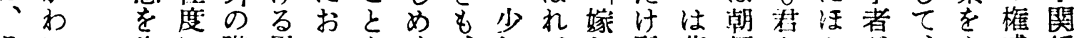

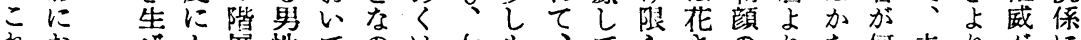

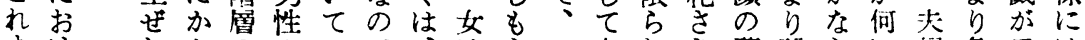

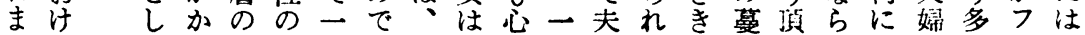




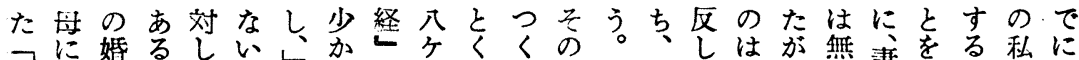

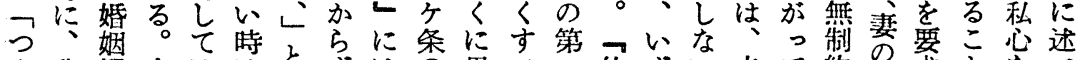

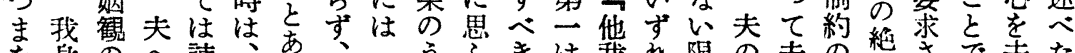

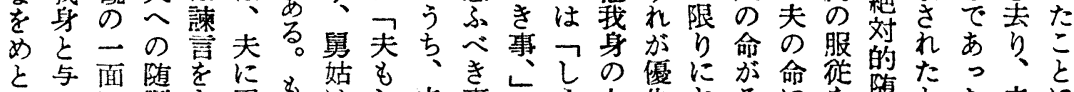

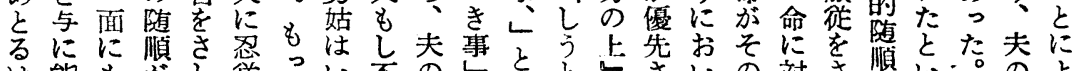

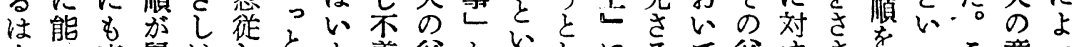

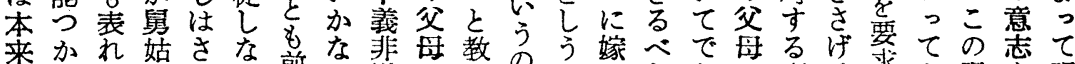

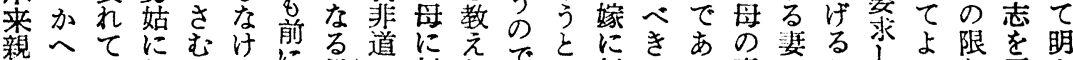

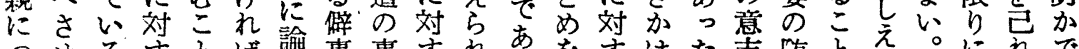

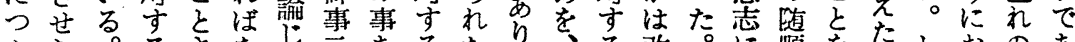

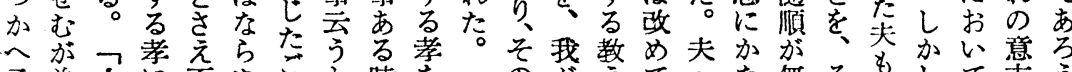

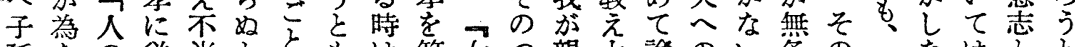

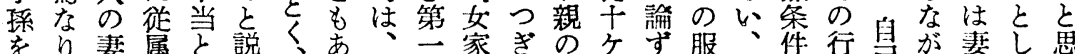

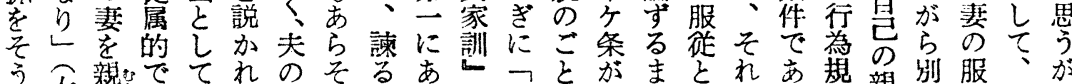

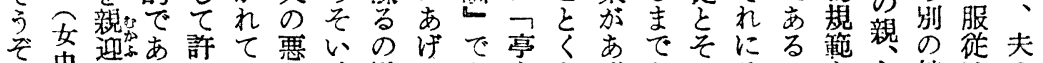

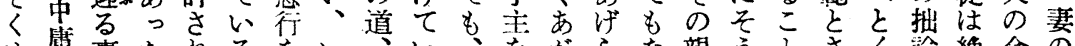

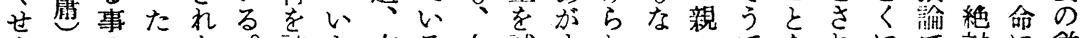
んとはこな。諫さ古る女誠まれいへてをれにで対に徒

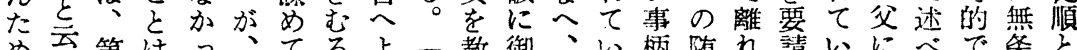

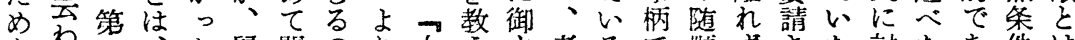
なわ二、た舅聞のり 女立孝るで㖻ずさた対たあ件は

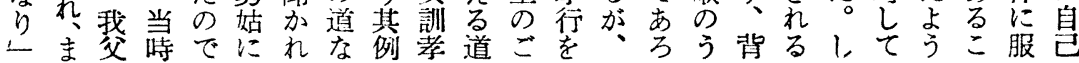

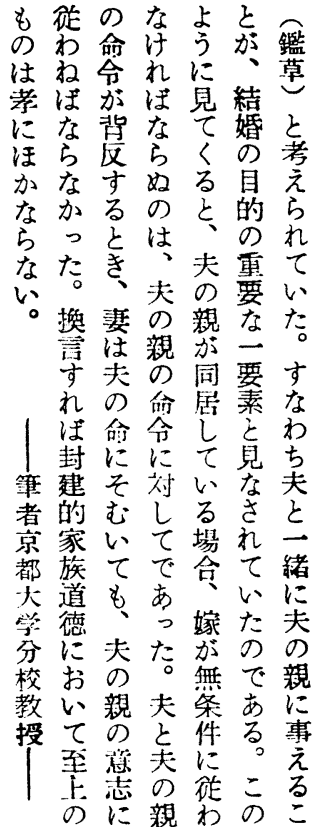




\section{The Vertical Relationship between Husband and Wife as Expressed in Feudal Morals.}

Tsutomu Himeoka

Kyoto University

Confucian morals in early modern Japan expounded the doctrine that th. ere existed an absolute distinction as great as that between heaven and earth between husband and wife, and parents and child. Furthermore, they were qualitatively different, i.e., the husband was compared to the difference between "on" and " $y \overline{0}$ ") the negative-female and positive-male elements in the universe, concepts of fundamental importance in Confucian doctrine.) But this meant nothing other than that the husband had superior status. Accordingly, wife who was inherently inferior was required to be absolutely obedient to her husband who was inherently superior. This principle held true even if the husband were completly unreasonable in his conduct or demands.

According to this doctrine husband and wife should be in accord with each other, and it was agreed that husband and wife were like a single body. But these were not doctrines proclaiming equality; on the contrary, they rested upon the principle of cooperation between superior and inferior. The feudal morals governing the husband-wife relationship did not set a high value on mutual love per se.

Buddist doctrine makes a similar qualitative distinction between husband and wife or male and female. This Buddist concept widely held and served reinforce the Confucian concept of female inferiority.

The obedience of wife to her husband was regarded as one of "three obediences" (i.e. in childhood woman should obey her parents; in marriage her husband; in old age her son). This lead to the view of woman as legally incompetent and denied her any moral autonomy.

Although obedience of the wife was required, when her husband's parents were alive, this duty was subordinate to that of obedience to his parents. In this sense obedience to the husband was not absolute duty. The paramout feudal moral principle was that of filial duty.

\section{Problems of Propaganda}

Katsu'ziko Nis'izimur.l

Kobe University

By propaganda, we mean those human activities that are carried on with the intension of directing man's behavior towards a given aim or goal by the use of certain symbols or signals.

Advertising is, in this sense, a species of propaganda which has as its 